\title{
The Relationship Between the Music Teacher Candidates' Computer-Assisted Teaching Attitudes and Exam Anxiety in Computer Literacy
}

\author{
Ismet Arici
}

Correspondence: Dr. Ismet Arici, Marmara University, Atatürk Faculty of Education, Department of Fine Arts, Department of Music Teacher Education, Istanbul, Turkey.

Received: August 26, 2018

doi:10.11114/jets.v6i11.3696
Accepted: September 25, $2018 \quad$ Online Published: October 17, 2018

URL: https://doi.org/10.11114/jets.v6i11.3696

\begin{abstract}
Today, improving instructional technologies have increased at a significant pace particularly with the introduction of computers in education. Computers have contributed greatly to every field of education. Computers have supported the preparation of powerful audio-visual materials with multiple-media features and have also empowered the education sector with the software options intended for different fields. Consequently; computer-assisted education (CAE) has come into its own.

As the use of computers has become widespread and computers have found an important place in education, attitudes about computer-assisted education have become important, as well. Particularly the empowerment of the attitudes of teacher candidates, as the educators of the future, toward computer-assisted education, is a significant gain for education.

Computer literacy lessons provided for in education faculties are significant in that they may help teacher candidates to prepare computer-assisted education materials and to use computers effectively in education process.

Finding out whether the attitudes toward computer-assisted education have positive impact on exam anxiety in computer lessons, analysing the factors which determine the attitudes, and understanding the reasons for anxiety will be useful in carrying out new researchers in order to make significant contributions to education processes.

This research included 46 teacher candidates studying Computer-Assisted Music Teaching in the Department of Music Teaching Education at Marmara University. The students completed the exam anxiety inventory and CAE attitude scale prior to administration of the computer-assisted music education exam. The results of the research indicated a significant negative relationship between the students' CAE attitude levels and their anxiety levels. Findings of the scales showed that, CAE attitudes were high and anxiety levels were low. Findings of the study indicated that the computer education they received contributed positively to their computer experiences and their attitudes towards CAE.
\end{abstract}

Keywords: computer assisted education, test anxiety, instructional technologies

\section{Introduction}

Today, several tools are used to create an effective educational environment. Computers are among these tools. The significance of computers in education and the most significant feature distinguishing a computer from other tools is that, it can be used as a means of production, teaching, management, presentation and communication (Yalın, 2007 quoted by: Sezer, 2011).

Computers can used in various ways in the educational environment and including Computer-Assisted Education (CAE). Odabaşı (1998) defines CAE as the practices related with the use of computers as a learning-teaching tool for directly presenting lesson contents, repeating the things learned through other methods, solving problems, doing exercises and other similar activities. Though they may seem as different practices, CAE practices have many similarities in terms of their application, duties, ways of use and purposes (Dinçer, 2006 quoted by: Yıldırım and Kaban, 2010).

Knowing the previous experiences or deficiencies of teachers about computers, their attitudes toward computers, and finally, the relationships between these experiences and attitudes towards computers, is significant for understanding one of the obstacles/deficiencies that might come out in the deployment of relevant technologies in teaching-learning processes and for developing solution offers for these (Deniz, 2003). 
The $20^{\text {th }}$ century witnessed the collapse of the industry-based economy and the rising of a knowledge-based society. The fast-paced development of technology in the age of knowledge will transform the style of education, as well. The Music industry and music education have already benefited from these innovations such as electronic synthesizers, computers, computer software, digital recording and re-forming techniques (Choksy et al., 2000: 24, 25).

It seems inevitable that the traditional way of production will change and technology will become determinant. Music education and teaching should also change in parallel with this (Bayraktar, 1993: 140).

A holistic approach combining the scientific, artistic and technological approaches should be followed to improve music teaching. This is because musical education involves all these three approaches today, it is like a compound of the three. Therefore; these three dimensions, particularly the artistic approach, should always be used when improving music teaching (Uçan, 1993: 153).

In institutions, which train music teachers in Turkey, it is possible to provide education about music technologies in courses "Computer I" and "Computer II" which are taught in two terms. In music teaching curriculum of the Council of Higher Education, "Computer II" course involves "Basic concepts about computer-assisted education, its components, theoretical foundations, benefits and limitations, ways of application, common formats used in computer-assisted education, assessment and selection of course software, distance education applications, database applications, the negative impact of computer and internet on children/youth and prevention of these" (YOK, 1998).

Developments in computers technologies and thus, in educational technologies, has adopted at the field of music education, just as the other fields of education, and have led it towards a radical change. The rich variety of the technologies used in teaching, disseminating the musical knowledge and in creating music, is the main factor accelerating this change. The technological system with the greatest impact on music education enabling radical changes, is the computer, which is defined as "the most effective communication and individual teaching method". Computers and computer software can undertake the functions of a music teacher in several aspects. Day by day, they have gained a crucial role in music education and in $21^{\text {st }}$ century, these technologies have become an inseparable part of music education (Levendoğlu, 2004).

Today computer-assisted music education lessons are widespread at music teacher training schools in Turkey.

In broad terms, anxiety is defined as an emotional state where weakness is felt while preparing for a danger which is felt. In some people, anxiety is observed as a continuous state and comes out as a personal. State anxiety is defined as the reaction given to a certain state in a certain time. Finally, there is event anxiety, which is experienced in the presence of certain events (Kılınçkaya, 2013).

Today, there are still theoretical discussions on the issue whether anxiety is an inborn character arising from genetic factors or is learned through environmental factors. On the other hand, the argument of Spielberger (1966) is generally accepted. In his two-state anxiety approach, Spielberger defines state anxiety and trait anxiety as the following: State anxiety is the emotional reaction that arises when the individuals perceive certain states as a threat. Trait anxiety is one's tendency to experience anxiety. This could also be defined as the individual's tendency to perceive and comprehend the states as being stressful. Individuals with high trait anxiety experience state anxiety more frequently and intensively than others (Quoted by: Özusta, 1995). Individuals experiencing trait anxiety feel an unexplainable trouble when making a call, doing shopping or even going on a vacation. On the other hand; individuals experiencing state anxiety feel anxious only in certain conditions. For example, they may feel exam anxious until they take the exam or until they learn about the exam result, they don't feel anxious in other conditions (Kutlu, 2001: 12-13).

Zeidner (2007) defines exam anxiety as 'the unpleasant feelings and emotional states experienced by the student during an exam or any assessment'. The characteristics of exam anxiety is similar to general anxiety. According to Dykemann (1992), there are two basic views about the source of anxiety. The first of these is that, students with insufficient learning and study skills, who feel insufficiency during the organization stage of the exam preparation process, exhibit a high level of exam anxiety. According to this view, some students do not have the organization stage needed for retrieving knowledge and they feel highly anxious during exams. The problem with these students is not the exam itself, but the preparation process for the exam. The second main reason is the habitual, unnecessary and negative opinions of some students during and throughout the exam. If the students have negative past images of themselves and of the patterns that come out during exams, but that are not related with the exam, learned helplessness shows up (quoted from Yurdabakan, 2005 by Güleç et al., 2013).

In this study, music teacher candidates completed to exam anxiety inventory and attitude scale for computer-assisted education prior to the Computer-Assisted Music Education exam. The findings were analysed to explore the relationship between the CAE (Computer-Assisted Education) attitude and exam anxiety. Furthermore, CAE attitude levels and the factors of exam anxiety were analysed. 


\section{Methods}

The research is in relational screening model. Relational screening models are research models aiming to determine the presence and/or degree of covariance in two or more variables (Karasar, 2002: 81).

The sample group of the research consists of 46 students, as 30 boys and 16 girls, studying Computer-Assisted Music Education in Marmara University, Department of Music Teacher Education.

\subsection{Measuring Tool}

At the beginning of the computer-assisted music education exam, the students were exposed to the anxiety inventory developed by Necla Öner and Deniz Albayrak, in order to determine their exam anxiety.

This inventory consists of 20 items and quartet-scale (1=Never; 2=Sometimes; 3=Often; 4=Always). Reliability of the scale was analysed and reliability coefficient was found as $\mathrm{r}=.95$. This high reliability value showed that it was suitable for use in the study (Öner \& Kaymak, 1987).

The computer-assisted education (CAE) scale developed by Arslan (2006) was used in order to determine the attitudes of the participants towards computer-assisted education.

Of the 20 items in the scale, 10 had positive and 10 had negative quality. Kaiser-Meyer-Olkin (KMO) coefficient of the scale was 0.88, and the Barlett Test significance value was 0.001 Cronbach-alpha reliability coefficient of the scale was 0.93 (Arslan, 2006).

\subsection{Statistical Methods}

Pearson Correlation Analysis, independent group t-test and frequency analysis were used in data analysis.

\section{Results}

Table 1. Gender-based variance of the relationship between the CAE attitude levels and exam anxiety states of the students

\begin{tabular}{lllll}
\hline & Variables & $\mathrm{n}$ & $\mathrm{r}$ & $\mathrm{p}$ \\
\hline \multirow{2}{*}{ Girls } & Attitude scale & \multirow{2}{*}{16} & -0.614 & 0.01 \\
\cline { 2 - 5 } & Anxiety scale & \multirow{2}{*}{30} & -0.284 & 0.12 \\
\cline { 2 - 5 } Boys & Antitude scale & & \multirow{2}{*}{ Anxiety scale } & \\
\hline
\end{tabular}

Table 1 shows that the relationship between the attitude levels of the participants and the anxiety states differ according to the gender variable. It was observed that the negative meaningful relationship between the variables was in favor of women.

Table 2. Gender-independent Group t-test results of the anxiety values

\begin{tabular}{lcccccc}
\hline \multirow{2}{*}{ Groups } & \multirow{2}{*}{$\mathrm{N}$} & $\mathrm{x}$ & $\mathrm{Ss}$ & \multicolumn{3}{c}{$\mathrm{t}$ Test } \\
\cline { 5 - 7 } & & & & $\mathrm{t}$ & $\mathrm{sd}$ & $\mathrm{p}$ \\
\hline Boys & 30 & 46.60 & 9.86 & \multirow{2}{*}{1.88} & \multirow{2}{*}{44} & 0.06 \\
\hline
\end{tabular}

The results of the independent t-test performed to determine whether the values of anxiety changed depending on gender, revealed out no significance difference.

Table 3. The relationship between the CAE attitude levels and exam anxiety states of the students

\begin{tabular}{lccc}
\hline Variables & $\mathrm{N}$ & $\mathrm{r}$ & $\mathrm{p}$ \\
\hline $\begin{array}{l}\text { Attitude scale } \\
\text { Anxiety scale }\end{array}$ & 46 & -0.342 & 0.02 \\
\hline
\end{tabular}

As is seen in Table 3, the Pearson Correlation Analysis performed to determine whether there was a significant relationship between the attitude levels and anxiety states of the students forming the study group revealed out a significant negative relationship between the variables $(r=-0.342 ; \mathrm{p}<0.05)$.

As the level of CAE attitude increases, the level of anxiety decreases. This indicates that, positive attitudes towards computer-assisted education help reducing the levels of anxiety felt when taking the exam of this lesson. 
Table 4. Gender-independent group t-test results of the CAE attitude values

\begin{tabular}{|c|c|c|c|c|c|c|}
\hline \multirow{2}{*}{ Groups } & \multirow{2}{*}{$\mathrm{N}$} & \multirow{2}{*}{$\overline{\mathrm{x}}$} & \multirow{2}{*}{ Ss } & \multicolumn{3}{|c|}{$\mathrm{t}$ Test } \\
\hline & & & & $\mathrm{t}$ & $\mathrm{sd}$ & $\mathrm{p}$ \\
\hline Boys & 30 & 83.93 & 11.97 & \multirow{2}{*}{1.31} & \multirow{2}{*}{44} & \multirow{2}{*}{0.19} \\
\hline Girls & 16 & 78.43 & 15.96 & & & \\
\hline
\end{tabular}

The results of the independent t-test performed to determine whether the values of attitude changed depending on gender, revealed out no significance difference.

Table 5. Descriptive statistics about the CAE attitude levels of the students

\begin{tabular}{ccccc}
\hline \multicolumn{1}{l}{ Scale } & & $\mathbf{n}$ & \multicolumn{1}{c}{$\mathbf{x}$} & \multicolumn{1}{c}{ Ss } \\
\hline CAE attitude scale & & 46 & 4.10 & 0.67 \\
\hline Option & Score Range & Level & \\
Strongly disagree & $1.00-1.80$ & Very low & \\
Disagree & $1.81-2.60$ & Low & \\
Neutral & $2.61-3.40$ & Moderate & \\
Agree & $3.1-4.20$ & High & \\
Strongly agree & $4.21-5.00$ & Very high &
\end{tabular}

The highest value that can be obtained from the CAE attitude scale is 5, and the lowest value is 1 . In Table 5, the mean value of CAE attitude scale is shown as 4.10. This means that value indicates that teacher candidates have a high attitude towards computer-assisted education. 
Table 6. Frequency percentage findings of the CAE attitude scale

\begin{tabular}{|c|c|c|c|c|c|c|c|}
\hline & & $\frac{5}{4}$ & 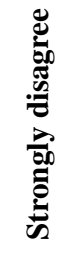 & 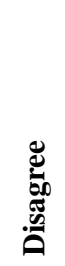 & $\begin{array}{l}\bar{\Xi} \\
\bar{\Xi} \\
\text { Z }\end{array}$ & 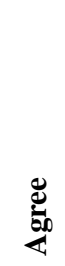 & 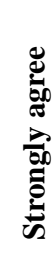 \\
\hline \multirow[t]{2}{*}{1.} & I use computers willingly and gladly in class & $f$ & 1 & 1 & 6 & 20 & 18 \\
\hline & & $\%$ & 2.2 & 2.2 & 13 & 43.5 & 39.1 \\
\hline \multirow[t]{2}{*}{2.} & CAE is an important issue for me & $f$ & 1 & 1 & 6 & 20 & 18 \\
\hline & & $\%$ & 2,2 & 2.2 & 13 & 43.5 & 39.1 \\
\hline \multirow[t]{2}{*}{3.} & I search for the ways to use computer more effectively in my classes & $f$ & 2 & 1 & 10 & 20 & 13 \\
\hline & & $\%$ & 4.3 & 2.2 & 21.7 & 43.5 & 28.3 \\
\hline \multirow[t]{2}{*}{4.} & Students learn better in classes where computers are used & $f$ & 1 & 2 & 10 & 14 & 19 \\
\hline & & $\%$ & 2.2 & 4.3 & 21.7 & 30.4 & 41.3 \\
\hline \multirow[t]{2}{*}{5.} & Teachers should be encouraged to use computers & $f$ & 0 & 0 & 0 & 21 & 25 \\
\hline & & $\%$ & 0 & 0 & 0 & 45.7 & 54.3 \\
\hline \multirow[t]{2}{*}{6.} & Computer is an effective tool in attracting the attention of students & $f$ & 0 & 2 & 2 & 17 & 25 \\
\hline & & $\%$ & 0 & 4.3 & 4.3 & 37 & 54.3 \\
\hline \multirow[t]{2}{*}{7.} & Computer-assisted classes are enjoyable & $f$ & 0 & 1 & 5 & 19 & 21 \\
\hline & & $\%$ & 0 & 2.2 & 10,9 & 41.3 & 45.7 \\
\hline \multirow[t]{2}{*}{8.} & Computers should be actively used in each class & $f$ & 0 & 0 & 10 & 16 & 20 \\
\hline & & $\%$ & 0 & 0 & 21.7 & 34.8 & 43.5 \\
\hline & I think computer is an effective teaching tool & $f$ & 0 & 0 & 6 & 24 & 16 \\
\hline & & $\%$ & 0 & 0 & 13 & 52.2 & 34.8 \\
\hline & I try to use computers in my classes & $f$ & 0 & 3 & 8 & 17 & 18 \\
\hline & & $\%$ & 0 & 6.5 & 17.4 & 37 & 39.1 \\
\hline & Computer cannot be effectively used in education & $f$ & 15 & 19 & 6 & 2 & 4 \\
\hline & & $\%$ & 32.6 & 41.3 & 13 & 4.3 & 8.7 \\
\hline & & $f$ & 13 & 17 & 6 & 7 & 3 \\
\hline \multirow[t]{2}{*}{12.} & Unless necessary, I don't use computers to assist the lesson & $\%$ & 28.3 & 37 & 13 & 15.2 & 6.5 \\
\hline & & $f$ & 22 & 15 & 3 & 2 & 4 \\
\hline \multirow[t]{2}{*}{13.} & Students cannot improve their creativity in CAE-based classes & $\%$ & 47.8 & 32.6 & 6.5 & 4.3 & 8.7 \\
\hline & & $f$ & 24 & 14 & 3 & 0 & 5 \\
\hline & I cannot relate computer with education & $\%$ & 52.2 & 30.4 & 6,5 & 0 & 10.9 \\
\hline & & $f$ & 27 & 14 & 0 & 0 & 5 \\
\hline & I prefer teaching the topic myself to using CAE & $\%$ & 58.7 & 30.4 & 0 & 0 & 10.9 \\
\hline & & $f$ & 20 & 16 & 6 & 0 & 4 \\
\hline & CAE is a waste of time & $\%$ & 43.5 & 34.8 & 13 & 0 & 8.7 \\
\hline & & $f$ & 20 & 16 & 6 & 0 & 4 \\
\hline & With CAE, students learn less compared to other methods or techniques & $\%$ & 43.5 & 34.8 & 13 & 0 & 8.7 \\
\hline & & $f$ & 21 & 17 & 2 & 2 & 4 \\
\hline & The contribution of CAE doesn't compensate for the efforts invested & $\%$ & 45.7 & 37 & 4.3 & 4.3 & 8.7 \\
\hline & & $f$ & 18 & 17 & 5 & 2 & 4 \\
\hline & wouldn't consider using computer as mean of education during classes & $\%$ & 39.1 & 37 & 10.9 & 4.3 & 8.7 \\
\hline & & $f$ & 20 & 16 & 3 & 4 & 3 \\
\hline & I would like to stop using computer as soon as possible & $\%$ & 43.5 & 34.8 & 6.5 & 8.7 & 6.5 \\
\hline
\end{tabular}

Table 6 remarkably shows that participants strongly agree with certain positive statements.

For the statement "I use computers willingly and gladly in class", 20 participants (43.5\%) marked the option "agree", 18 participants (39.1\%) marked the option "strongly agree" and a total of 38 participants (82.6\%) agreed with the positive statements.

For the statement "CAE is an important issue for me" 20 participants (43.5\%) marked the option "agree", 18 participants (39.1\%) marked the option "strongly agree" and a total of 38 participants $(82.6 \%)$ agreed with the positive statements.

The same percentages are valid for the statement "I search for the ways to use computer more effectively in my classes".

For the statement "Teachers should be encouraged to use computers", 21 participants (45.7\%) marked the option "agree", 25 participants (54.3\%) marked the option "strongly agree". This shows that all the participants (100\%) supported teachers' use of computers and had a positive attitude towards computer-assisted education.

For the statement "I think computer is an effective teaching tool", 24 participants (52.2\%) marked the option "agree", 16 participants (34.8\%) marked the option "strongly agree". A total of 40 participants (87\%) support this statement. 6 participants remained neutral (13\%).

These statistical findings show that teacher candidates attach great importance to the role of computer in education. 
Table 7. Descriptive statistics about the anxiety states of the students

\begin{tabular}{lcccc}
\hline Scale & & $\mathbf{n}$ & $\mathbf{x}$ & Ss \\
\hline Anxiety scale & & 46 & 2.22 & 0.51 \\
\hline Option & Score Range & Level & \\
Never & $1.00-1.74$ & Very low & \\
Sometimes & $1.75-2.49$ & Low & \\
Often & $2.50-3.24$ & High & \\
Always & $3.25-4.00$ & Very high &
\end{tabular}

The highest value that can be obtained from the anxiety scale is 4 , and the lowest value is 1 . In Table 7 , the mean value of the exam anxiety attitude scale is shown as 2.22 . This means that value indicates that teacher candidates have a low level of anxiety in computer exam in general.

Table 8 . Frequency percentage findings for the exam anxiety inventory

\section{EXAM ANXIETY INVENTORY}

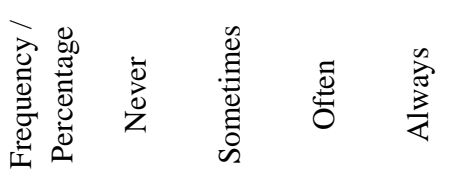

\begin{tabular}{|c|c|c|c|c|c|c|}
\hline \multirow[t]{2}{*}{1.} & \multirow[t]{2}{*}{ I feel safe and comfortable during an exam } & $f$ & 5 & 26 & 12 & 3 \\
\hline & & $\%$ & 10.9 & 56.5 & 26.1 & 6.5 \\
\hline \multirow[t]{3}{*}{2.} & \multirow{2}{*}{$\begin{array}{l}\text { Thinking about the grade I am going to take from a lesson negatively affects my } \\
\text { success in the exam }\end{array}$} & $f$ & 6 & 16 & 15 & 9 \\
\hline & & $\%$ & 13 & 34.8 & 32.6 & 19.6 \\
\hline & & $f$ & 9 & 25 & 10 & 2 \\
\hline 3. & I get petrified in important exams. & $\%$ & 19.6 & 54.3 & 21.7 & 4.3 \\
\hline \multirow[t]{3}{*}{4.} & \multirow{2}{*}{$\begin{array}{l}\text { During the exams I can't help thinking whether I will be able to finish the school one } \\
\text { day }\end{array}$} & $f$ & 20 & 15 & 8 & 3 \\
\hline & & $\%$ & 43.5 & 32.6 & 17.4 & 6.5 \\
\hline & & $f$ & 7 & 25 & 9 & 5 \\
\hline \multirow[t]{2}{*}{5.} & The harder I try in an exam, the more confused I get & $\%$ & 15.2 & 54.3 & 19.6 & 10.9 \\
\hline & & $f$ & 7 & 23 & 8 & 8 \\
\hline \multirow[t]{2}{*}{6.} & I feel uneasy and uncomfortable in exams & $\%$ & 15.2 & 50 & 17.4 & 17.4 \\
\hline & & $f$ & 12 & 16 & 14 & 4 \\
\hline \multirow[t]{2}{*}{7.} & I feel frustrated during an important exam & $\%$ & 26.1 & 34.8 & 30.4 & 8.7 \\
\hline & & $f$ & 8 & 16 & 15 & 7 \\
\hline \multirow[t]{2}{*}{8.} & I think about being unsuccessful, which disrupts my concentration in the exam & $\%$ & 17.4 & 34.8 & 32.6 & 15.2 \\
\hline & & $f$ & 22 & 17 & 5 & 2 \\
\hline \multirow[t]{2}{*}{9.} & I feel very nervous even in exams for which I studied well & $\%$ & 47.8 & 37 & 10.9 & 4.3 \\
\hline & & $f$ & 15 & 22 & 6 & 3 \\
\hline \multirow[t]{2}{*}{10.} & I feel so tense during important exams that I feel sick & $\%$ & 32.6 & 47.8 & 13 & 6.5 \\
\hline & & $f$ & 12 & 23 & 10 & 1 \\
\hline \multirow[t]{2}{*}{11.} & I feel uneasy just before taking an exam paper back & $\%$ & 26.1 & 50 & 21.7 & 2.2 \\
\hline & & $f$ & 23 & 16 & 5 & 2 \\
\hline \multirow[t]{2}{*}{12.} & I almost push myself toward defeat during important exams & $\%$ & 50 & 34.8 & 10.9 & 4.3 \\
\hline & & $f$ & 6 & 21 & 11 & 8 \\
\hline \multirow[t]{2}{*}{13.} & I feel very nervous during exams & $\%$ & 13 & 45.7 & 23.9 & 17.4 \\
\hline & & $f$ & 7 & 20 & 12 & 7 \\
\hline \multirow[t]{2}{*}{14.} & I get panicked during an important exam & $\%$ & 15.2 & 43.5 & 26.1 & 15.2 \\
\hline & & $f$ & 5 & 6 & 6 & 29 \\
\hline \multirow[t]{2}{*}{15.} & I wish exams did not disturb me so much & $\%$ & 10.9 & 13 & 13 & 63 \\
\hline & & $f$ & 8 & 20 & 11 & 7 \\
\hline \multirow[t]{2}{*}{16.} & I feel very anxious before taking an important exam & $\%$ & 17.4 & 43.5 & 23.9 & 15.2 \\
\hline & & $f$ & 11 & 23 & 9 & 3 \\
\hline \multirow[t]{2}{*}{17.} & During an exam, I can't help thinking about the consequences of failing the exam & $\%$ & 23.9 & 50 & 19.6 & 6.5 \\
\hline & & $f$ & 9 & 22 & 8 & 7 \\
\hline \multirow[t]{2}{*}{18.} & I feel my heart beat fast during important exams & $\%$ & 19.6 & 47.8 & 17.4 & 15.2 \\
\hline & & $f$ & 15 & 14 & 11 & 6 \\
\hline \multirow[t]{2}{*}{19.} & After an exam, I try not to get anxious but I can't help it & $\%$ & 32.6 & 30.4 & 23.9 & 13 \\
\hline & & $f$ & 14 & 23 & 4 & 5 \\
\hline 20. & I become so frustrated during exams that I even forget the things I know & $\%$ & 30.4 & 50 & 8.7 & 10.9 \\
\hline
\end{tabular}

Whereas the exam anxiety levels of the teacher candidates are low in general, Table 8 remarkably shows that there are certain statements where the participants display a high level of anxiety.

For the statement "Thinking about the grade I am going to take from a lesson negatively affects my success in the exam", 15 participants (32.6\%) marked the option "often" and 9 participants (19.6\%) marked the option "always". This means, a 
total of 24 participants (52.2\%) reported that they became anxious about grades. One of the basic methods to eliminate this is to have the students adopt the idea that learning is more important than marks.

For the statement "I feel uneasy and uncomfortable in exams", 8 participants (17.4\%) marked the option "often" and 8 participants (17.4\%) marked the option "always". The total number of participants marking these options make 16, which corresponds to $34.8 \%$.

For the statement "I feel very nervous during exams", 11 participants (23.9\%) marked the option "often" and 8 participants (17.4\%) marked the option "always". The total number of participants marking these options make 19, which corresponds to $41.3 \%$.

The rates of agreement with these statements indicate that students feel uneasy and nervous during exams. This shows how important it is for teachers to display an attitude aimed at the elimination of this nervousness.

\section{Discussion and Conclusion}

Analysis of the research findings has revealed out a significant negative relationship between the computer-assisted education attitudes and exam anxiety levels of music teaching candidates.

The research has shown that, teacher candidates have attitude towards computer-assisted education. This finding is closely related with their consideration of computer as an effective mean of education. In this research, the exam anxiety inventory was applied particularly before the exam of the computer-assisted music education course. It can be concluded that, positive attitudes towards computer-assisted education is an important factor in the obtainment of low scores in exam anxiety.

Improvement of attitudes towards computer-assisted education has become even more important with the increasing use of computer in education. Therefore, programs on computer education should be intensified in educational institutions. It is crucial, in terms of both technical hardware and software, to have a well-established infrastructure.

Şahin and Akçay (2011) reported at the end of their research that, there was no significant relationship between the teacher candidates who owned a computer and who didn't, with respect to their attitude towards computer-assisted education. This result could be claimed to be arising from the fact that, teacher candidates had the opportunity to use computers and internet inside and outside their campus, even if they didn't have their own computer, they used internet as a source for preparing their assignments and they took two lessons on computers.

In a research conducted by Bindak (2005) it was reported that, teachers who owned a computer had a significantly higher attitude compared to those who didn't (Şahin and Akçay, 2011).

Consequently, it is important that teachers and teacher candidates own a computer and use computers both in their life and in their education process. It would be useful to take the following measures in order to reduce exam anxiety in computer lesson:

- To encourage the students to use computers, to have them perform extracurricular educational project assignments and computer-assisted studies

- To help them adopt the idea that the basic issue about education is not the mark but learning

- To set up a comfortable environment that will reduce their excitement and nervousness during exams

\section{References}

Arslan, A. (2006). The attitude scale toward making computer supported education. Yüzüncü Yll University, Journal of Education Faculty, 3(2), 24-33

Bayraktar, E. (1993). An Overview of Music Teaching in Our Country. Ankara: Music Encyclopedia Publications

Choksy, L., \& Others (2000). Teaching Music in the Twenty-First Century. 2nd edition. Englewood Cliffs, NJ: Prentice-Hall.

Deniz, L. (2003). The relationship between computer attitudes and computer experiences of student teachers. Atatürk Faculty of Education Journal of Educational Sciences, 18, 39-64.

Dykeman, B. F. (1992). Coping with test anxiety. College Teaching, 40, 147-150. https://doi.org/10.1080/87567555.1992.10532238

Güleç, S., \& Others (2013). Examination of Relationship between Student Teachers' Time Management Skills and Test Anxiety Levels. Uludağ University Journal of Education Faculty, 26(2), 343-358.

Karasar, N. (2002). Scientific Research Methodology. Nobel Publications, Ankara

Kılınçkaya, M. D. (2013). The relationship between test anxiety and students' achievement in Atatürk's principles and 
revolution course. Hacettepe University. Journal of Education, 28(1), 235-243.

Kutlu, Ö. (2001). Adolescent anxiety caused by university entrance examinations. Education and Science, 26(121), $12-23$.

Levendoğlu, O. (2004). Technology-supported music education in the age of 1924-2004. (Announcement) Symposium of the Music Teacher Training Symposium from Musiki Muallim Mektebi, Suleyman Demirel University, April 7-10, Isparta

Öner, N., \& Kaymak, D. (1987). The magnitude and reliability of the test anxiety inventory English form. Journal of Psychology, 6(21), 55-62.

Şahin, A., \& Akçay, A. (2011). An analysis of Turkish language teacher candidates' attitudes towards computer assisted education. Turkish Studies - International Periodical for The Languages, Literature and History of Turkish or Turkic, 6(2), 909-918. https://doi.org/10.7827/TurkishStudies.2288

Sezer, A. (2011). Investigation of Attitudes of Geography Teacher Candidates on Computer Assisted Instruction. Uşak University Journal of Social Sciences, 4(1), 1-19.

Uçan, A. (1993). How to Improve Music Teaching. Ankara: Music Encyclopedia Publications

Yildırım, S., \& Kaban, A. (2010). Attitudes of pre-service teachers about computer supported. Education, Journal of Human Sciences, 7(2), 158-167.

YÖK (1998). Music Teaching Program. Ankara: Higher Education Council

Zeidner, M. (2007). Test Anxiety in Educational Contexts: concepts, findings, and future directions. (Ed. Paul A. Schutz, Reinhard Pekrun ve Gary D. Phye). Emotion in Education, Burlington: Elseveir.

\section{Copyrights}

Copyright for this article is retained by the author(s), with first publication rights granted to the journal.

This is an open-access article distributed under the terms and conditions of the Creative Commons Attribution license which permits unrestricted use, distribution, and reproduction in any medium, provided the original work is properly cited. 